\title{
OPEN Environmental stressors, complex interactions and marine benthic communities' responses
}

\author{
Charlotte Carrier-Belleau ${ }^{1 \bowtie}$, David Drolet ${ }^{2}$, Christopher W. McKindsey ${ }^{1,2} \&$ \\ Philippe Archambault ${ }^{1}$
}

The increasing number and diversity of anthropogenic stressors in marine habitats have multiple negative impacts on biological systems, biodiversity and ecosystem functions. Methods to assess cumulative effects include experimental manipulations, which may identify non-linear responses (i.e. synergies, antagonisms). However, experiments designed to test these ideas are uncommon, generally focusing on single biological responses. We conducted a manipulative experiment to investigate the isolated and combined effects of warming $\left(+6^{\circ} \mathrm{C}\right.$ ), salinity variation (freshwater pulses or presses), and nutrient enrichment (natural or enriched) following one and three month's exposure, on responses measured at multiple levels of biological complexity in a simple bivalve assemblage. More specifically, we determined effects on bivalve mortality, growth, shell mineralization, and energy content, as well as microphytobenthos biomass. Salinity variation and nutrient enrichment, individually and combined, caused strong impacts on some of the measured variables and their effect varied through time. In contrast, warming had no effect. Our work highlights the prevalence of antagonistic interactions, the importance of examining effects of single and multiple stressors through time, and of considering multiple responses to understand the complexity behind stressor interactions.

Humans have a considerable influence on ecosystems, and scientific evidence of the human footprint on terrestrial, freshwater, and marine ecosystems is now irrefutable ${ }^{1-3}$. Continuous growth of human populations and use of natural systems have increased the number and diversity of anthropogenic environmental stressors ${ }^{4}-$ here defined as factors (of natural or anthropogenic origin) perturbing an ecosystem beyond its natural limits of variation ${ }^{5}$. Human activities (e.g. agriculture, fishing, coastal development) together with anthropogenically induced global climate change (e.g. warming) are provoking profound and irreversible changes in coastal marine ecosystems through the emergence of multiple stressors, such as organic pollution, elevated temperature, and salinity changes ${ }^{6}$. Such stressors impact biological processes, alter ecosystem functions, and decrease global and local biodiversity ${ }^{4,7-9}$.

While stressors may occur in isolation, globally $97.7 \%$ of the ocean is currently affected by more than one stressor ${ }^{10}$. The spatial and temporal superposition of stressors catalyzes the emergence of complex relationships: i.e. synergistic or antagonistic interactions ${ }^{7}$. Synergistic interactions occur when the combined effect of two or more stressors are greater than the sum of the individual stressors (i.e. additive effect), commonly considered as the null model. In contrast, when the combined effect of multiple stressors leads to a smaller response than that predicted by the null model, the interaction is considered antagonistic ${ }^{11-14}$. When multiple stressors act in opposite directions on a biological response, the interpretation of these interactions becomes even more complex. For instance, if the combined response of two stressors is more positive than the additive expectation, it would be considered a positive synergistic effect. In contrast, if the combined response is more negative than the additive expectation it would be deemed a negative synergistic effect. The same logic applies to antagonistic interactions $\mathrm{s}^{14,15}$. However, one stressor may dominate another and account for $100 \%$ of the biological response measured (i.e. dominance effect). While determining the presence of complex interactions is challenging, it is essential to identify environmental priorities for conservation actions in coastal areas, which are typically affected by greater than 100 two-way interactions between stressors ${ }^{7,16,17}$.

In the context of multiple stressors, identifying synergistic and antagonistic interactions is of particular importance to inform management decisions since they may affect ecosystem responses to interventions ${ }^{18}$. This

${ }^{1}$ Québec-Océan, Department of Biology, Université Laval, 1045, av. de la Médecine, Québec G1V 0A6, Canada. ${ }^{2}$ Maurice Lamontagne Institute, Fisheries and Oceans Canada, 850 route de la Mer, Mont-Joli G5H 3Z4, Canada. ${ }^{\circledR}$ email: charlotte.carrier.belleau@gmail.com 
may be done by informing environmental managers on which stressors to act upon and when and where it is most effective or necessary to intervene ${ }^{16,17,19,20}$. For example, if a single stressor acts synergistically with several others, then action upon this one might generate a disproportionate positive ecosystem response. On the other hand, antagonistic interactions may lead to overall negative effects if all stressors are not addressed together.

However, an important disconnect exists between the investigation of the combined effects of multiple stressors and the implementation of conservation and management practices ${ }^{7,20}$. In this context, a perfect understanding and prediction of the effects of multiple stressors is an unrealistic objective ${ }^{21}$. Identifying generalities about stressors, responses, and interaction types may better inform decision makers in their conservation and legislative actions. To do so, it is essential to design ecologically realistic experiments that consider the impact of local stressors (e.g. nutrient input, overfishing) within the context of global stressors (e.g. climate change) ${ }^{16}$. Global stressors cannot be halted by local actions whereas local stressors may be acted upon effectively and directly manipulated through management actions ${ }^{16}$. For example, reducing a local stressor, such as fishing or nutrient input, may improve recovery rates from uncontrollable stressors, such as climate change $\mathrm{e}^{22}$.

Many tools exist to understand biological consequences of natural and anthropogenic stressors at physiological $^{23}$, population ${ }^{24,25}$ and ecosystem levels ${ }^{26,27}$. However, effects of stressors on populations may differ from those on individuals, making it crucial to better understand the mechanisms affecting biological organization by looking at the effect of multiple stressors on multiple responses ${ }^{13,15,28,29}$.

Of the emerging stressors in shallow coastal areas, eutrophication has gained considerable attention over recent decades ${ }^{30}$. Despite this, the effects of nutrient enrichment on benthic communities remain poorly understood, especially in combination with other stressors ${ }^{31-33}$. The influence of salinity changes has also been a central focus of studies on estuarine ecosystem biodiversity, which is commonly reduced along haline gradients from marine to brackish conditions $s^{34,35}$. For instance, salinity changes in estuaries may arise from high discharge during freshets, heavy rain events-which are expected to increase in intensity and occurrence due to climate change, wastewater discharges, or upriver flow regulation (e.g. hydropeaking) ${ }^{36,37}$. In addition, global warming represents a major driver of ecosystem change as it threatens habitats, ecological communities, and many natural processes ${ }^{38,39}$. For example, warming is frequently suggested to exacerbate the effects of local stressors, such as nutrient enrichment, which, together, may enhance macroalgal recruitment and triggering blooms in coastal waters ${ }^{40,41}$.

The aim of this study was to determine the short-term effect of multiple stressors alone and in combination on multiple biological responses in two model bivalve species and the type of interactions resulting from stressor combinations using an experimental approach. More specifically, based on the environmental context and parameters measured in an anthropized bay of the Gulf of St. Lawrence estuary (Quebec, Canada) ${ }^{42}$, we concentrated our research effort on determining the impacts of anthropogenically induced nutrient inputs, shortterm salinity variations, and elevated temperature. The combined and individual effects of these stressors were evaluated by measuring mortality, growth, shell mineralization, and energy content in the blue mussel Mytilus sp. and Baltic clam Limecola balthica, as well as chlorophyll $a$ in sediments as a measure of microphytobenthic biomass after one- and three-months exposure to these stressors. When stressors interacted, we determined the nature of the effect, discriminating between dominant, additive, synergistic and antagonistic interactions and how it varied after the two exposure periods. We hypothesized that the three stressors would act in isolation (i.e. dominance effect, additive) or interact (i.e. synergistic and antagonistic interaction) depending on the response variable, knowing stressors, such as temperature, nutrient enrichment and salinity variation, have different effects depending on the biological compartment of interest ${ }^{13,15}$. We also hypothesized that the individual and combined effect of the stressors would vary through time, as it has been suggested that the effect of multiple stressors depends on the time scale ${ }^{43}$.

These two bivalve species, like many benthic species, are both sedentary and exposed to stressors in natural ecosystems; they are thus logical indicators and models to assess the effect of stressors ${ }^{44}$. Mytilus sp. can survive at considerably low salinities, but growth and biomass increase once the salinity reaches $25 \mathrm{psu}^{45}$, while $L$. balthica can live and reproduce successfully in a broader range of salinities (2-35 psu $)^{46}$. Nutrient enrichment, on the other hand, will logically increase organic matter and may lead to mortality in Mytilus sp. ${ }^{47}$ although it has been suggested that L. balthica may benefit from nutrient enrichment and be used as an indicator of organic pollution ${ }^{48}$. Both species commonly inhabit intertidal areas and are thus accustomed to large temperature fluctuations. For example, Mytilus sp. can tolerate temperatures ranging from 3 to $27^{\circ} \mathrm{C}$ in the study area, with growth optimum between 10 and $20^{\circ} \mathrm{C}^{45}$, while L. balthica is associated to cooler temperatures ${ }^{49}$. L. balthica may, however, tolerate short exposure to elevated temperatures $\left(37.5^{\circ} \mathrm{C}\right)$, but may experience an energetic lost associated with a sub-optimal metabolic function ${ }^{49}$.

It is hoped that this study will demonstrate the potential complexity of interactions between contemporary multiple stressors on primary and secondary production, thus stressing the difficulty of undertaking logical environmental management actions in the face of such complexity.

\section{Materials and methods}

Sediment collection, characterization and preparation. We collected sediments in the bay of the Mitis River $\left(48^{\circ} 38^{\prime} \mathrm{N}, 68^{\circ} 08^{\prime} \mathrm{W}\right)$, a tributary of the St. Lawrence estuary (QC, Canada), and transported them to the adjacent Institute Maurice-Lamontagne (Fisheries and Oceans Canada, Mont-Joli, QC, Canada) in June 2018. Sediments were sieved on a 500 - $\mu \mathrm{m}$ mesh to remove all macroinfauna while retaining the microphytobenthos. Sediments were then transferred into $80 \mathrm{PVC}$ cylinders used as aquaria (height $=30 \mathrm{~cm}$, width $=10 \mathrm{~cm}$, sediment height $=12 \mathrm{~cm}$ ) and placed inside the experimental system one week before introducing the bivalves. To characterize initial conditions, Chlorophyll $a$, grain size, and organic matter were measured in the sediment of ten randomly selected aquaria using standard techniques a week prior to the start of the experiment ${ }^{50,51}$. 


\begin{tabular}{|c|c|c|c|c|c|c|c|c|c|c|c|}
\hline \multicolumn{3}{|l|}{ Treatments } & \multicolumn{9}{|c|}{ Measured experimental parameters } \\
\hline \multirow[b]{2}{*}{ Temperature } & \multirow{2}{*}{$\begin{array}{l}\text { Salinity } \\
\text { variation }\end{array}$} & \multirow[b]{2}{*}{ Nutrient } & \multicolumn{3}{|c|}{ Nutrient release $\left(\mathrm{mmol} \mathrm{m}^{-2}\right.$ day $\left.^{-1}\right)$} & \multirow{2}{*}{$\begin{array}{l}\text { Temperature } \\
\left({ }^{\circ} \mathrm{C}\right)\end{array}$} & \multirow{2}{*}{$\begin{array}{l}\text { Temperature } \\
\text { (pulse/press) }\end{array}$} & \multirow[b]{2}{*}{ Salinity PSU } & \multirow{2}{*}{$\begin{array}{l}\text { Salinity } \\
\text { (pulse/press) }\end{array}$} & \multirow[b]{2}{*}{ pH } & \multirow{2}{*}{$\begin{array}{l}\text { pH (pulse/ } \\
\text { press) }\end{array}$} \\
\hline & & & $\mathbf{P}$ & $\mathbf{N}$ & $\mathbf{K}$ & & & & & & \\
\hline Ambient & Pulse & $\mathrm{N}^{-}$ & - & - & - & $7.61( \pm 0.04)$ & $7.76( \pm 0.04)$ & $27.96( \pm 0.05)$ & $20.28( \pm 0.06)$ & $8.76( \pm 0.01)$ & $8.74( \pm 0.01)$ \\
\hline Ambient & Pulse & $\mathrm{N}^{+}$ & $\begin{array}{l}39.6928 \\
( \pm 1.7893)\end{array}$ & $\begin{array}{l}213.1646 \\
( \pm 9.6091)\end{array}$ & $\begin{array}{l}44.9218 \\
( \pm 2.0250)\end{array}$ & $7.61( \pm 0.04)$ & $7.76( \pm 0.04)$ & $27.96( \pm 0.05)$ & $20.28( \pm 0.06)$ & $8.76( \pm 0.01)$ & $8.74( \pm 0.01)$ \\
\hline Ambient & Press & $\mathrm{N}^{-}$ & - & - & - & $7.62( \pm 0.04)$ & $7.69( \pm 0.04)$ & $27.91( \pm 0.04)$ & $11.57( \pm 0.03)$ & $8.74( \pm 0.01)$ & $8.76( \pm 0.01)$ \\
\hline Ambient & Press & $\mathrm{N}^{+}$ & $\begin{array}{l}37.8973 \\
( \pm 0.9893)\end{array}$ & $\begin{array}{l}203.5212 \\
( \pm 5.3128)\end{array}$ & $\begin{array}{l}42.8895 \\
( \pm 1.1196)\end{array}$ & $7.62( \pm 0.04)$ & $7.69( \pm 0.04)$ & $27.91( \pm 0.04)$ & $11.57( \pm 0.03)$ & $8.74( \pm 0.01)$ & $8.76( \pm 0.01)$ \\
\hline Warming & Pulse & $\mathrm{N}^{-}$ & - & - & - & $13.50( \pm 0.03)$ & $14.06( \pm 0.04)$ & $28.14( \pm 0.05)$ & $20.52( \pm 0.05)$ & $8.73( \pm 0.02)$ & $8.74( \pm 0.01)$ \\
\hline Warming & Pulse & $\mathrm{N}^{+}$ & $\begin{array}{l}38.3835 \\
( \pm 1.6225)\end{array}$ & $\begin{array}{l}206.1328 \\
( \pm 8.7132)\end{array}$ & $\begin{array}{l}43.4399 \\
( \pm 1.8362)\end{array}$ & $13.50( \pm 0.03)$ & $14.06( \pm 0.04)$ & $28.14( \pm 0.05)$ & $20.52( \pm 0.05)$ & $8.73( \pm 0.02)$ & $8.74( \pm 0.01)$ \\
\hline Warming & Press & $\mathrm{N}^{-}$ & - & - & - & $13.52( \pm 0.03)$ & $13.96( \pm 0.04)$ & $27.98( \pm 0.05)$ & $11.50( \pm 0.03)$ & $8.74( \pm 0.01)$ & $8.77( \pm 0.01)$ \\
\hline Warming & Press & $\mathrm{N}^{+}$ & $\begin{array}{l}39.2434 \\
( \pm 0.8236)\end{array}$ & $\begin{array}{l}210.7512 \\
( \pm 4.4231)\end{array}$ & $\begin{array}{l}44.4132 \\
( \pm 0.9321)\end{array}$ & $13.52( \pm 0.03)$ & $13.96( \pm 0.04)$ & $27.98( \pm 0.05)$ & $11.50( \pm 0.03)$ & $8.74( \pm 0.01)$ & $8.77( \pm 0.01)$ \\
\hline
\end{tabular}

Table 1. Mean $( \pm S E)$ values of experimental parameters measured or calculated in mixing tanks (temperature, salinity) or aquaria (nutrients) over the duration of the experiment for all treatments: phosphorus $(\mathrm{P})$, nitrogen $(\mathrm{N})$, and potassium $(\mathrm{K})$ release $\left(\mathrm{mmol} \mathrm{m}^{-2} \mathrm{~d}^{-1}\right)$, temperature $\left({ }^{\circ} \mathrm{C}\right)$, salinity $(\mathrm{PSU})$ and $\mathrm{pH}$ during regular conditions and freshwater pulses and presses. Pulse treatments corresponded to periodical moderate drops of salinity six times per day: 9:00-9:30, 13:00-13:30, 17:00-17:30, 21:00-21:30, 01:0 0-01:30, 5:00-5:30. The press treatment corresponded to a single intense drop of salinity from 9:00 to 12:00.

We measured chlorophyll $a$ in the first $\mathrm{cm}$ of sediments as an indicator of microphytobenthos biomass using a protocol adapted from Riaux-Gobin and Klein ${ }^{50}$. On average, we found $1.0380 \mu \mathrm{g}$ (SE =0.0880) of chlorophyll $a$ $\mathrm{g}^{-1}$ dry sediment. Sediment grain size was determined for the top five $\mathrm{cm}$ of sediments using a Laser Diffraction Particle Size Analyzer (LA-950, HORIBA Scientific, Kyoto, Japan) and classified sediment types as follows: mud $(<3.9 \mu \mathrm{m})$, silt $(3.9 \mu \mathrm{m}<\mathrm{X}<62.5 \mu \mathrm{m})$, sand $(62.5 \mu \mathrm{m}<\mathrm{X}<2 \mathrm{~mm})$ and gravel $(>2 \mathrm{~mm})^{52,53}$. An average of $54.34 \%$ $(\mathrm{SE}=0.5866)$ of sediment particles was sand whereas $38.8 \%(\mathrm{SE}=0.2171)$ was mud. Initial percentage organic matter was characterized following Davies ${ }^{51}$ and averaged 3.26\% (SE $\left.=0.0009\right)$. Chlorophyll $a$, grain size, and organic matter did not differ substantially among analyzed aquaria and any variation was assumed to be random.

Organism collection, transport and maintenance. Blue mussels (Mytilus sp.) (Linnaeus, 1758) and Baltic clams (Limecola balthica) (Linnaeus, 1758) were collected by hand in the same bay as the sediment in June 2018. Specimens were transported to the laboratory in water buckets within an hour of collection and were blotted, measured (length, width, height) and weighed. They were then tagged on the right outer shell using bee marking numbers (The Bee Works, Orillia, ON, Canada). Specimens were maintained two months in the laboratory in a tank supplied with a continuous flow of unfiltered seawater $\left(1.500 \mathrm{~L} \mathrm{~min}^{-1}\right)$. After 2 months of acclimation to laboratory conditions, specimens were introduced to the experimental system. We selected juveniles ranging from 2 to $2.5 \mathrm{~cm}$ for Mytilus sp. and 1 to $1.5 \mathrm{~cm}$ for L. balthica. Eight individuals of each species were randomly placed together in each aquarium, this reflecting their naturally occurring densities at the sampling site (mean \pm SE: $15 \mathrm{~m}^{-2} \pm 0.56$ and $14 \cdot \mathrm{m}^{-2} \pm 0.54$, respectively), for a total of 640 per species. The two species occur together in the St. Lawrence; while Mytilus sp. is found attached on rocks or on soft substrates, $L$. balthica is found only in sediments.

Experimental design, system and protocol. The experiment was performed between August $1^{\text {st }}$ and October $23^{\text {rd }}, 2018$. We assigned each aquarium randomly to one of the 16 experimental treatments following a full-factorial design ( $\mathrm{n}=5$ aquaria per treatment) (Table 1, Supplementary Figure S1).

The intensities of the three stressors were selected to reflect conditions observed in the St. Lawrence and to stay within, but at the limit of, both species' tolerances to temperature, salinity, and nutrient enrichment. The temperatures used mimicked average temperatures of surface waters in coastal areas of the Gulf of St. Lawrence and surface anomalies recorded in recent years ${ }^{54}$. We used two stable temperatures for the duration of the experiment: ambient temperature recorded at this time of the year $\left(7.5^{\circ} \mathrm{C}\right)$ and an increase of $6{ }^{\circ} \mathrm{C}\left(13.5^{\circ} \mathrm{C}\right)$ that corresponds to anomalies recorded in the surface layers $(0-50 \mathrm{~m})$ of different locations in the estuary and Gulf of St. Lawrence (Table 1$)^{54}$. For stress induced by salinity variations, we generated pulses and presses of freshwater instead of using stable salinities as being intertidal, the organisms are used to being exposed to freshwater during low tide and salt-water during high tide. The pulse treatment corresponded to periodic drops of salinity, passing from ambient salinity (i.e. $28 \mathrm{psu}$ ) to a salinity of 20 psu for $30 \mathrm{~min}$, six times per day. The press treatment corresponded to a single drop of salinity passing from ambient to a salinity of 12 psu for three hours. These treatments were not measured in situ but selected to represent either small natural or anthropogenic variations in salinity (e.g. continuous wastewater release) versus presses linked to extreme climatic events caused by global change (e.g. spring freshet or increased river flow). Here, we a priori considered the press treatment to be more stressful, due to its greater variation in intensity and its longer time of exposure. We used natural levels of nutrients of the sediments or an in situ enrichment technique using controlled-release fertilizer pellets (Osmocotes, Acer NT NPK 17-7-10, Plant-Prod, Brampton, ON, Canada) (Table 1). We used $30 \mathrm{~g}$ of pellets in mesh bags and dug 
them into the sediments, $8 \mathrm{~cm}$ from the surface, one week prior to the start of the experiment. We weighed the fertilizer pellets before and at the end of the experiment to characterize the daily N, P, and K release. Nutrient release was judged to not differ over time as fertilizer pellet loss per unit time was roughly equivalent following one and three months of experimental conditions (mean \pm SE: $5.30 \mathrm{~g} \pm 0.0898$ and $15.87 \mathrm{SE} \pm 0.1278$, respectively). The technique and quantity of nutrients released was similar to those used in other experiments simulating nutrient enrichment and investigating their impact on benthic communities ${ }^{30,55,56}$. For natural conditions, we placed mesh bags filled with small pebbles in the sediments to control for possible effects of mesh bags in aquaria.

The experimental set up was an open system consisting of two header tanks, eight independent tanks to obtain the desired mix of salinity and temperatures (mixing tanks, $n=2$ salinity-temperature treatment) and 80 aquaria (experimental units, $n=5$ per treatment) (Supplementary Figure S1). The desired temperatures were obtained using titanium coils immersed in the head tanks to warm or cool filtered sea water supplied directly from the St. Lawrence and fresh municipal drinking water. Salinity was controlled by regulating salt- and freshwater inputs to mixing tanks using flow meters and timers to obtain a total flow of $150 \mathrm{~L} \mathrm{~h}^{-1}$, which enabled us to avoid the use of an additional aeration system. We used flexible airline tubing to randomly link each mixing tank to ten aquaria, for a total of eighty experimental aquaria. The experimental units were placed in $80 \mathrm{~L}$ water baths to keep the sediments at desired temperatures. Each water bath housed two randomly distributed replicates for each salinity/nutrient treatment at a given temperature for a total of 8 aquaria per water bath (Supplementary Figure S1). The aquaria were exposed to a 12 -h photoperiod (7:00 to 19:00) by using $62^{\prime} \times 4^{\prime}$ LED panels (72 W) that were placed $30 \mathrm{~cm}$ above the water bath. Temperature, salinity, and $\mathrm{pH}$ in the eight mixing tanks were measured daily during freshwater pulses and presses with a multiprobe (Table 1). Salinity and temperature were also recorded in ten haphazardly selected aquaria during each freshwater pulse and press to ensure experimental conditions did not differ from those in mixing tanks. Oxygen was measured ten times in all aquaria during the experiment and never fell below $90 \%$ at the surface of the sediments. Due to unfortunate events, two experimental units were lost after three months of exposure (Warming-Press- $\mathrm{N}^{-}$and Ambient-Press- $\mathrm{N}^{-}$).

Organisms were fed twice per day with Shellfish diet 1800 (Reed mariculture, Campbell, CA, USA)—a mix of six marine microalgae: Isochrysis strain (CCMP1324), Pavlova strain (CCMP459), Tetraselmis strains (PLY 429), Chaeotoceros calcitrans, Thalassiosira weissflogii and Thalassiosira pseudonana. $180 \mathrm{~mL}$ of Shellfish diet 1800 was diluted in $1.7 \mathrm{~L}$ of sea water and $21.25 \mathrm{~mL}$ was transferred to each aquarium with a graduated plastic pipette at 10:00 and 16:00. After one- and three-months exposure, half of the aquaria in each water bath (i.e. one of each treatment) were collected and processed as described below.

Chlorophyll a biomass. Chlorophyll $a$ was evaluated as a proxy for microphytobenthos biomass in our experimental units. The upper $1 \mathrm{~cm}$ of sediments from each aquarium was sampled with a $10 \mathrm{~mL}$ disposable syringe, placed in a $15 \mathrm{~mL}$ Falcon tube, and frozen at $-80^{\circ} \mathrm{C}$ for subsequent analysis. Pigment concentrations were determined fluorometrically (Turner 10AU, San Jose, CA, USA) following a modified Riaux-Gobin and Klein protocol ${ }^{50}$. The results are expressed as $\mu \mathrm{g} \mathrm{g}^{-1} \mathrm{dry}$ sediment.

Mortality and growth. At the end of the experiment, individual bivalves were carefully retrieved from the sediments. Mortality, defined as the percentage of dead individuals for each species, was determined by identifying dead individuals and empty shells. Shell metrics (length, width, height) and mass of each surviving individual were taken and compared to initial sizes to characterize growth ( $\mathrm{mm})$. Even though juveniles invest more energy in growth than do adults ${ }^{57}$, thus justifying our focus on juveniles, we did not expect growth, as bivalve growth is significantly reduced by August in the St. Lawrence ${ }^{58}$. Individuals were then dissected and the mass of each shell and tissue measured using a precise scale (blotted weight). Shells were individually placed in parafilm and tissues in Eppendorf tubes and both frozen at $-80^{\circ} \mathrm{C}$ until they were evaluated for minerals and energy content, respectively.

Shell mineralization. Shell mineral concentrations were determined as marine organisms possess calcium carbonate structures that provide protection, support for muscle contraction, and are directly and indirectly involved in various physiological functions (e.g. acid-base balance and osmo-ionic regulation $)^{59}$. In particular, we focused on the major mineral components of the shell: calcium $\left(\mathrm{Ca}^{2+}\right)$, magnesium $\left(\mathrm{Mg}^{2+}\right)$, and strontium $\left(\mathrm{Sr}^{2+}\right)$. In addition, to help interpret the results on potential changes in single cation concentrations, we calculated the ratios between $\mathrm{Mg}^{2+}$ and $\mathrm{Ca}^{2+}$ and $\mathrm{Sr}^{2+}$ and $\mathrm{Ca}^{2+}$, which are indicators of change in mineralization status of exoskeletal structures ${ }^{60-62}$. Changes in concentrations of given minerals can provide evidence for potential dissolution of the shell or plastic mineral responses. For example, a lower concentration of magnesium and a lower $\mathrm{Mg}^{2+}-\mathrm{Ca}^{2+}$ ratio suggest the shell may be more tolerant to acidification but more vulnerable to mechanical stresses or predation ${ }^{6364}$. To control for passive dissolution of the shells under all experimental conditions, three empty shells of each species were weighed (dry weight) at the beginning of the experiment and placed in each aquarium (total of 15 per species per treatment). Following one or three-months exposure, shells were recovered and weighed to evaluate loss.

Three Mytilus sp. and three L. balthica from each aquarium were haphazardly selected and their shells cleaned using plastic tools to avoid mineral contamination (total of 15 per species per treatment $)^{65}$. We then cryo-lyophilized (Freezone 12 Floor Model, Labconco, Kansas City, USA) the shells for $48 \mathrm{~h}$ at $-40{ }^{\circ} \mathrm{C}$ to remove residual moisture. Each dry shell was then weighed, ground, and $0.056 \mathrm{~g}(\mathrm{SE}=0.0007)$ placed in a $15 \mathrm{~mL}$ Falcon tube for digestion. For digestion, we added $3 \mathrm{~mL}$ of nitric acid (65-70\%) and $1 \mathrm{~mL}$ of hydrogen peroxide (25-35\%). After $24 \mathrm{~h}$, we placed samples for $2 \mathrm{~h}$ in a sonication bath at $45^{\circ} \mathrm{C}$ to accelerate digestion. Once the samples were completely digested, shell minerals were determined at Geo Labs (Sudbury, ON, Canada) using an inductively coupled plasma (ICP) optical emission spectrometer (Spectro Arcos II ICP-OES, SPECTRO, Kleve, Germany) 


\begin{tabular}{|c|c|c|c|c|c|c|c|c|c|c|c|}
\hline \multirow[b]{3}{*}{ Source of variation } & \multirow[b]{3}{*}{ DF } & \multicolumn{6}{|c|}{ Mortality } & \multicolumn{4}{|c|}{ Chlorophyll $a$} \\
\hline & & \multicolumn{3}{|c|}{ Mytilus sp. } & \multicolumn{3}{|c|}{ Limecola balthica } & \multirow[b]{2}{*}{ DF } & \multirow[b]{2}{*}{ MS } & \multirow[b]{2}{*}{ Pseudo F } & \multirow[b]{2}{*}{$P$} \\
\hline & & MS & Pseudo F & $P$ & MS & Pseudo F & $P$ & & & & \\
\hline $\mathrm{T}$ & 1 & 1.065 & $2.042 \times 10^{-2}$ & ns & 200.84 & 0.580 & ns & 1 & 160.24 & 5.340 & * \\
\hline $\mathrm{W}$ & 1 & 30.725 & 0.589 & ns & 538.95 & 1.556 & ns & 1 & 1.497 & $4.988 \times 10^{-2}$ & ns \\
\hline S & 1 & 169.93 & 3.257 & ns & 181.81 & 0.525 & ns & 1 & 64.46 & 2.148 & ns \\
\hline $\mathrm{N}$ & 1 & 22.834 & 0.438 & ns & 132.65 & 0.383 & ns & 1 & 18.869 & 0.629 & ns \\
\hline $\mathrm{T} \times \mathrm{W}$ & 1 & 9.588 & 0.184 & ns & $1.315 \times 10^{-2}$ & $3.797 \times 10^{-5}$ & ns & 1 & 64.366 & 2.145 & ns \\
\hline $\mathrm{T} \times \mathrm{S}$ & 1 & 1.065 & $2.042 \times 10^{-2}$ & ns & 1223.5 & 3.532 & ns & 1 & 120.71 & 4.023 & * \\
\hline $\mathrm{T} \times \mathrm{N}$ & 1 & 14.323 & 0.275 & ns & 104.18 & 0.301 & ns & 1 & $2.134 \times 10^{-2}$ & $7.112 \times 10^{-4}$ & ns \\
\hline $\mathrm{W} \times \mathrm{S}$ & 1 & 23.57 & 0.452 & $\mathrm{~ns}$ & 15.332 & $4.426 \times 10^{-2}$ & ns & 1 & 20.396 & 0.680 & ns \\
\hline $\mathrm{W} \times \mathrm{N}$ & 1 & 79.336 & 1.521 & ns & 1.89 .85 & 0.548 & ns & 1 & 8.044 & 0.268 & ns \\
\hline $\mathrm{S} \times \mathrm{N}$ & 1 & 230.33 & 4.415 & * & 0.812 & $2.344 \times 10^{-3}$ & ns & 1 & 10.328 & 0.344 & ns \\
\hline $\mathrm{T} \times \mathrm{W} \times \mathrm{S}$ & 1 & 9.588 & 0.184 & ns & 24.969 & $7.208 \times 10^{-2}$ & ns & 1 & 72.316 & 2.410 & ns \\
\hline $\mathrm{T} \times \mathrm{W} \times \mathrm{N}$ & 1 & 0.118 & $2.269 \times 10^{-3}$ & ns & 63.66 & 0.184 & ns & 1 & 16.243 & 0.541 & ns \\
\hline $\mathrm{T} \times \mathrm{S} \times \mathrm{N}$ & 1 & 14.323 & 0.275 & ns & \begin{tabular}{|l|}
148.98 \\
\end{tabular} & 0.430 & ns & 1 & 5.404 & 0.180 & ns \\
\hline $\mathrm{W} \times \mathrm{S} \times \mathrm{N}$ & 1 & 7.367 & 0.141 & ns & 61.586 & 0.178 & ns & 1 & 1.893 & $6.307 \times 10^{-2}$ & ns \\
\hline $\mathrm{T} \times \mathrm{W} \times \mathrm{S} \times \mathrm{N}$ & 1 & 0.118 & $2.269 \times 10^{-3}$ & ns & 70.089 & 0.202 & ns & 1 & 4.454 & 0.148 & ns \\
\hline \begin{tabular}{|l|} 
Residual \\
\end{tabular} & 62 & 52.175 & & & \begin{tabular}{|l|}
346.4 \\
\end{tabular} & & & 50 & 30.008 & & \\
\hline Total & 77 & & & & & & & 66 & & & \\
\hline
\end{tabular}

Table 2. Results of PERMANOVA analyses investigating the effect of exposure time (T), temperature (W), salinity variation (S) and nutrient enrichment $(\mathrm{N})$ on mortality levels in the common mussel, Mytilus sp. and the Baltic clam, L. balthica and on chlorophyll $a$ concentration in sediments. The factors temperature (W), salinity variation $(\mathrm{S})$ and nutrient enrichment $(\mathrm{N})$ were set as fixed. Details are provided for degree of freedom (DF), mean square (MS), Pseudo-F and probability level $(P)$.

in axial configuration using the custom analytical method based on the parameters of the current water analysis method on the ICP-AES, IAW-200. Geo Labs proceeded to dilutions of a factor of 50 to have sufficient solution for the analysis and to match the instrument's tolerance limits. The results are expressed in $\mathrm{mmol} \mathrm{kg}^{-1} \mathrm{dry}$ shell.

Energy content. The effects of single and combined stressors on tissue energy content was determined using the soft tissues of the whole body of two individuals per aquarium (total of 10 per species per treatment). The tissues were first weighed and dried $24 \mathrm{~h}$ at $65^{\circ} \mathrm{C}$ (GO1340A-1 Lindberg/Blue M, Thermo fisher Scientific, Waltham, USA). After $24 \mathrm{~h}$, dry samples were weighed and then ground to a pellet. Due to the relatively small size of samples, we added a known quantity of benzoic acid to the pellets to raise energy outputs to the calibration level. The heat emitted by the benzoic acid was then removed when calculating the energy of the tissues. The analysis was carried out with a semi-microbomb calorimeter (6725, Parr Instrument Co., Moline, IL, USA), a precision thermometer (6772, Parr Instrument) and oxygen bomb (1109A, Parr Instrument) following the protocol established by Siddon et al. ${ }^{66}$. We used $1 \mathrm{~g}$ benzoic pellets (3416, Parr Instrument Company, Moline, USA) for calibration at the beginning of each measurement interval. To control for the heat potentially emitted by the nitric acid obtained from the nitrogen in the bomb, wash water from 10 samples was titrated with $\mathrm{NaOH}$ $(0.1 \mathrm{M})$. Means of this correction factor were included in the formula used to determine tissue energy. Results are expressed as $\mathrm{kJ} \mathrm{g}^{-1}$ dry mass.

Statistical Analysis. The effects of single and combined stressors were analyzed using permutational multivariate analysis of variance (PERMANOVA) based on Euclidean distance with PRIMER v.6 ${ }^{67,68}$, where the terms "Temperature" (two levels_ambient and warming), "Salinity variation" (two levels—pulse and press), "Nutrient status" (two levels-natural and enriched) and "Exposure time" (two levels-1 and 3 months) were included as fixed factors for mortality and chlorophyll $a$ biomass (Table 2). For energy content and shell mineralization, since measurements were carried out at the individual level, we added the term "aquarium" as a random factor, with "Exposure time", "Temperature", "Salinity variation" and "Nutrient status" nested in "Aquarium" (Tables 3, 4). Due to very low concentrations of chlorophyll $a$ in the samples, 11 samples fell below detection levels. These were removed from the statistical analysis for chlorophyll $a$ as they provided negative values. Beforehand, we tested the effect of the $80 \mathrm{~L}$ water bath and mixing tanks on mortality, chlorophyll $a$ biomass, energy content and shell mineralization to verify any potential experimental bias. No significant variation was observed. We set the possibility of making a type I error to $\alpha=0.05$. Homoscedasticity of residuals was verified using the test of homogeneity of dispersions (PERMDISP). We used pair-wise comparisons among given sources of variation of interest to further evaluate significant interactions to understand which levels differed.

Interactions interpretation. To help interpret the nature of observed interactions, we used Piggott et al. ${ }^{14}$ interaction classifications based on an additive $(A+B)$ and multiplicative $((A+B)-(A \times B))$ effects model. The 


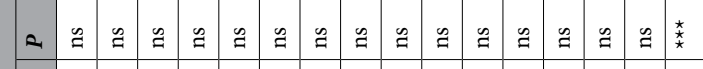

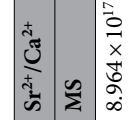

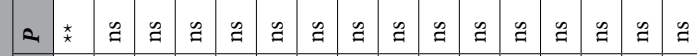

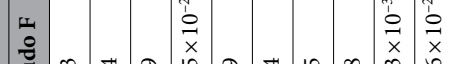

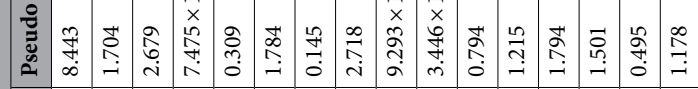

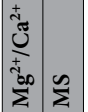

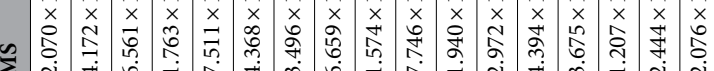

㟶

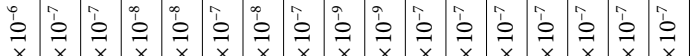

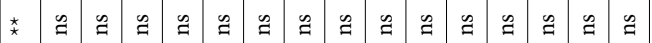

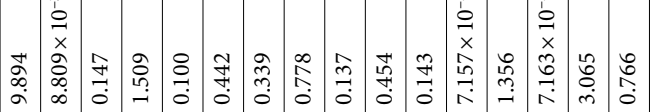

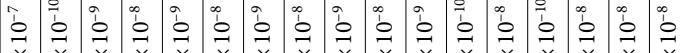

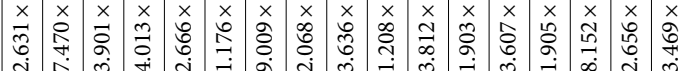

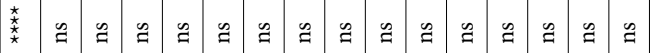

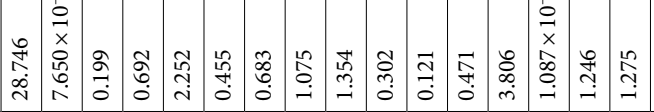

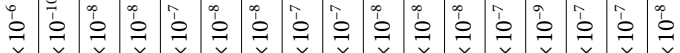

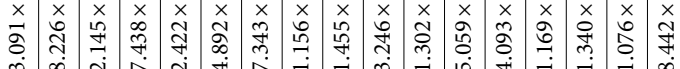

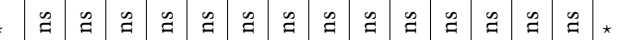

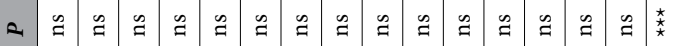

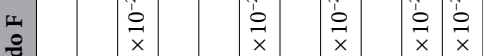

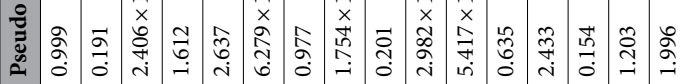

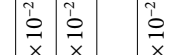

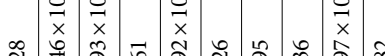

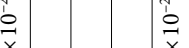

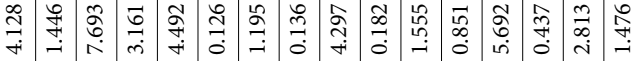

$\sin _{2}$ م)

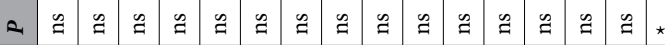

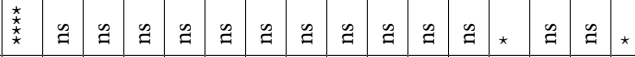

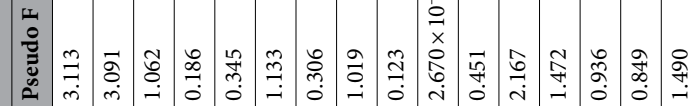

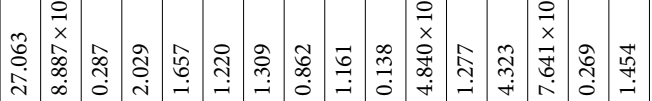

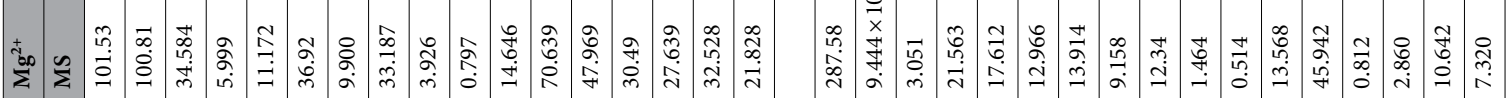

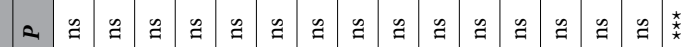
$\cong$

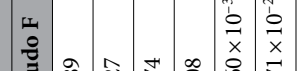

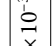

党 它全

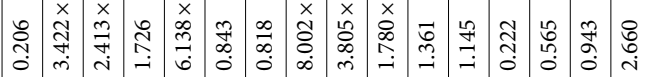

遂

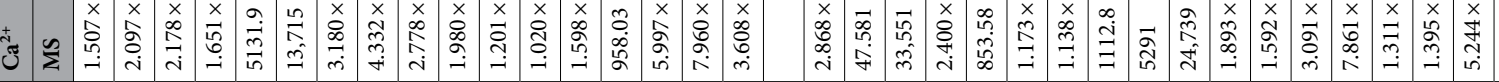

㟔

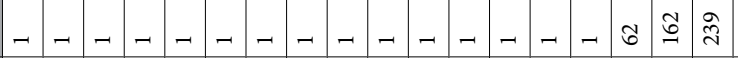

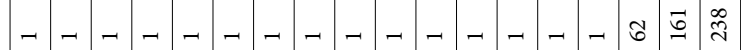

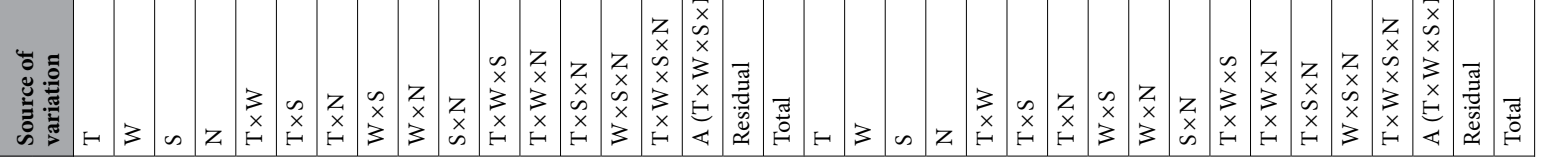

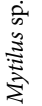
$\frac{\sqrt{3}}{3}$
总出 पै

:

昰

ज्ञ

ชี ซี

के

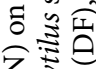

Z茫

苞苍

氖总

ฮี ฮั

䒕. ప્

壱

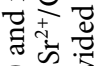

क्ञ

응

$\sum_{i}^{\infty} \frac{\pi}{3}$

:

灵.

S

3.

壱芯

䒕害争

들

버윯

.

$\exists$

䒽声䒕

पै

पे

㝳

胥寻

焉

:

背

吼

त)

สี Бี

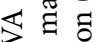

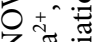

艺讨

疍宫

돔코

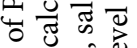

苞

幽莺苛

i

을 䒕 


\begin{tabular}{|c|c|c|c|c|c|c|c|c|}
\hline \multirow[b]{3}{*}{ Source of variation } & \multicolumn{8}{|c|}{ Energy content } \\
\hline & \multicolumn{4}{|c|}{ Mytilus sp. } & \multicolumn{4}{|c|}{ Limecola balthica } \\
\hline & DF & MS & Pseudo F & $P$ & DF & MS & Pseudo F & $P$ \\
\hline $\mathrm{T}$ & 1 & 3087.8 & 18.555 & $* * *$ & 1 & 2188 & 1.444 & ns \\
\hline $\mathrm{W}$ & 1 & 19,818 & 1.191 & $\mathrm{~ns}$ & 1 & 904.62 & 0.597 & ns \\
\hline$S$ & 1 & 33.913 & 0.204 & $\mathrm{~ns}$ & 1 & 39.933 & $2.635 \times 10^{-2}$ & $\mathrm{~ns}$ \\
\hline $\mathrm{N}$ & 1 & 410.7 & 2.468 & ns & 1 & 2432 & 1.605 & $\mathrm{~ns}$ \\
\hline $\mathrm{T} \times \mathrm{W}$ & 1 & 200.8 & 1.207 & ns & 1 & 3372.5 & 2.225 & ns \\
\hline $\mathrm{T} \times \mathrm{S}$ & 1 & 334.78 & 2.012 & ns & 1 & 153.1 & 0.761 & ns \\
\hline $\mathrm{T} \times \mathrm{N}$ & 1 & 147.95 & 0.889 & ns & 1 & 7658.5 & 5.053 & * \\
\hline $\mathrm{W} \times \mathrm{S}$ & 1 & 246.12 & 1.479 & ns & 1 & 790.8 & 0.528 & ns \\
\hline $\mathrm{W} \times \mathrm{N}$ & 1 & 50.476 & 0.303 & ns & 1 & 2.424 & $1.599 \times 10^{-3}$ & ns \\
\hline $\mathrm{S} \times \mathrm{N}$ & 1 & 27.132 & 0.163 & $\mathrm{~ns}$ & 1 & 1846.1 & 1.218 & ns \\
\hline $\mathrm{T} \times \mathrm{W} \times \mathrm{S}$ & 1 & 36.692 & 0.220 & $\mathrm{~ns}$ & 1 & 161.6 & 0.107 & ns \\
\hline $\mathrm{T} \times \mathrm{W} \times \mathrm{N}$ & 1 & 23.368 & 0.140 & ns & 1 & 3332.7 & 2.199 & ns \\
\hline $\mathrm{T} \times \mathrm{S} \times \mathrm{N}$ & 1 & 6.159 & $3.701 \times 10^{-2}$ & ns & 1 & 4142.8 & 2.734 & $\mathrm{~ns}$ \\
\hline $\mathrm{W} \times \mathrm{S} \times \mathrm{N}$ & 1 & 36.481 & 0.219 & ns & 1 & 4952.7 & 3.268 & ns \\
\hline $\mathrm{T} \times \mathrm{W} \times \mathrm{S} \times \mathrm{N}$ & 1 & 155.6 & 0.935 & ns & 1 & 43.869 & $2.895 \times 10^{-2}$ & $\mathrm{~ns}$ \\
\hline $\mathrm{A}(\mathrm{T} \times \mathrm{W} \times \mathrm{S} \times \mathrm{N})$ & 63 & 167.96 & 1.203 & $\mathrm{~ns}$ & 62 & 1546.1 & 1.462 & $\mathrm{~ns}$ \\
\hline Residual & 81 & 139.52 & & & 81 & 1057.4 & & \\
\hline Total & 159 & & & & 158 & & & \\
\hline
\end{tabular}

Table 4. Results of PERMANOVA analyses investigating the effect of exposure time (T), temperature (W), salinity variation $(\mathrm{S})$ and nutrient enrichment $(\mathrm{N})$ on energy content in the tissues of Mytilus sp. and $L$.

balthica ( $\mathrm{kJ} \mathrm{g}^{-1}$ of dry mass). The factors temperature $(\mathrm{W})$, salinity variation $(\mathrm{S})$, nutrient enrichment $(\mathrm{N})$ were set as fixed, and aquarium (A) as random. Details are provided for degree of freedom (DF), mean square (MS), Pseudo F and probability level $(P)$.

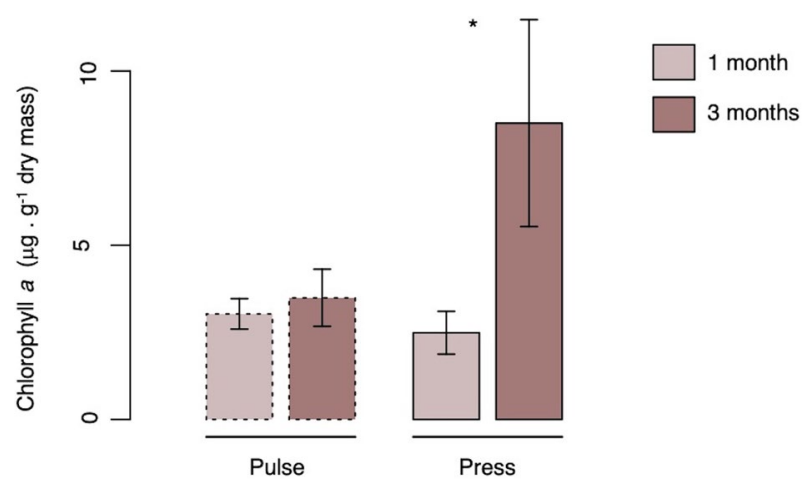

Figure 1. Effect of salinity variation through time on microphytobenthic standing stock. Average chlorophyll $a$ concentration ( $\mu \mathrm{g} \mathrm{g}^{-1} \mathrm{dry}$ mass) for salinity variation following one and three months of exposure. Pair-wise contrasts showed a significant difference between one and three-months of exposure within for freshwater presses $(\mathrm{p}<0.05)$ as indicated by the asterisk. Histograms represent mean values, and error bars correspond to standard errors.

model combines response magnitude and direction (positive or negative) of the combined effects of stressors considered relative to the effect observed under control conditions, as well as the deviation from a null model (additive or multiplicative model) to determine interaction type (synergism and antagonism). Here, we did not have a control condition but compared the combined effect of stressors to a least-stressful condition (ambient temperature, freshwater pulses, no nutrient enrichment). Therefore, when there were no significant interactions between the stressors (i.e. no significant interactions in PERMANOVA), we could identify dominance (i.e. combined effects are equal to that of one of the individual stressors) or additive (i.e. combined effects are equal to the algebraic sum of the individual effects of each stressor) effects $\mathrm{s}^{7}, 14$. When we identified two- or three-way interaction terms (i.e. significant interaction term in PERMANOVA), we characterized interactions as antagonistic or synergistic and noted their direction (less or more positive or negative than the null model) ${ }^{15}$. We used an additive null model for chlorophyll $a$, shell mineralization and energy content. For mortality, we used a multiplicative null model to correct for the issue that individuals killed by one stressor cannot be killed by another and the model sets the combined mortality to a maximum of $100 \%^{7,69}$. We did not consider the source of variation 
a

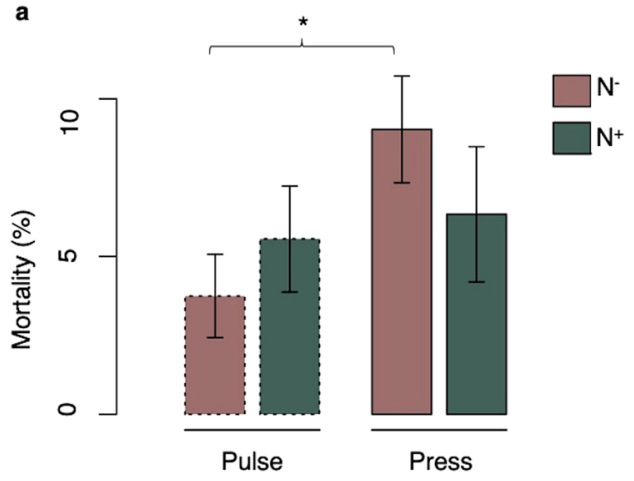

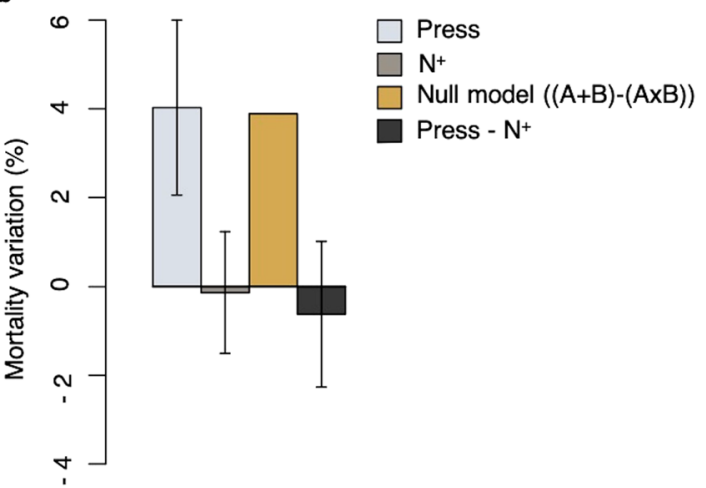

Figure 2. Effect of the interaction between salinity variation and nutrient enrichment on mortality levels in Mytilus sp. (a) Average mortality level (\%) for salinity treatments (S) and nutrient concentrations (N) in Mytilus sp. Pair-wise contrasts showed a significant difference between pulses and freshwater presses with natural nutrient concentrations $(\mathrm{p}<0.05)$ as identified by the asterisk. Histograms represent the mean value, and error bars correspond to standard errors. (b) Positive antagonistic interaction between freshwater presses and nutrient enrichment based on a null multiplicative model (yellow) $((S+N)-(S \times N))$. Single effects of stressors, compared to the least stressful conditions, are shown in light blue and gray and a combined effect is shown in dark gray. Error bars correspond to standard errors.

"Exposure time" as a stressor, but when an interaction between a stressor and "Exposure time" was detected, we concluded a dominance effect and verified whether it was consistent over time or not. When only two stressors interacted, we evaluated the results against a null model to detect synergistic or antagonistic interactions and evaluated consistency over time if "Exposure time" also interacted with the response.

\section{Results}

Microphytobenthos biomass. In general, chlorophyll $a$ concentration in the upper sediment layer was less than $5 \mu \mathrm{g} \mathrm{g}^{-1}$ dry sediment across all treatments but increased when affected by freshwater presses over time, as indicated by the significant Exposure time $\times$ Salinity interaction (Fig. 1, Table 2). This demonstrates a dominance of freshwater presses through time, as indicated by the significantly greater chlorophyll $a$ concentration after three months exposure to presses and that chlorophyll $a$ concentration did not vary over time under the effect of freshwater pulses. Mean concentrations of chlorophyll $a$ for all treatments are summarized in Supplementary Table S2.

Mortality and growth. In general, mortality was relatively low across all treatments for Mytilus sp., ranging between 0 and 10\%, and higher in L. balthica, ranging between 10 and 30\%. Mortality of Mytilus sp. varied significantly as a function of the Nutrient $\times$ Salinity interaction (Fig. 2, Table 2). Specifically, mortality in animals exposed to freshwater presses was higher in the absence of nutriment enrichment relative to those with nutriment enrichment. Animals exposed to pulses of freshwater were not affected by nutriment enrichment (Fig. 2a, Table 2). Following the null multiplicative $\operatorname{model}^{7}$, this indicates a positive antagonistic interaction (i.e. less positive than the null model) between the press freshwater regime and nutrient enrichment (Fig. 2b). Indeed, examination of individual stressors suggests that the press freshwater regime increased the average mortality by $4 \%$ relative to the least stressful conditions. Nutrient enrichment alone had no, or very slight, effects on mortality levels relative to the least stressful conditions. However, the combined effect of a press regime and nutrient enrichment was lower than the multiplicative expectation, thus resulting in reduced mortality levels relative to the least stressful conditions.

L. balthica mortality levels were not significantly affected by stressors, individually or in combination. Mean mortality levels for all treatments are summarized for both species in Supplementary Table S2. Finally, no growth was detected for either species across all treatments tested during the exposure period.

Shell mineralization. No loss of material from empty shells was detected over the experimental period, indicating that passive dissolution of shells did not occur under any experimental conditions tested over the one- and three-month exposure periods. Mean concentrations of all cations measured in both species for all treatments are summarized in Supplementary Table S1.

For Mytilus sp., exposure time had a significant effect on $\mathrm{Mg}^{2+} / \mathrm{Ca}^{2+}$ (Table 3) as the ratio was lower following three months than one month of exposure. No other major mineral shell components (i.e. $\left[\mathrm{Ca}^{2+}\right],\left[\mathrm{Mg}^{2+}\right],\left[\mathrm{Sr}^{2+}\right]$ and $\mathrm{Sr}^{2+} / \mathrm{Ca}^{2+}$ ) varied as a function of any of the evaluated factors.

In contrast, several major mineral shell components varied as a function of Time for L. balthica (Fig. 3a, Table 3). For example, shell $\left[\mathrm{Mg}^{2+}\right]$ varied as a function of the Exposure time $\times$ Salinity $\times$ Nutrient interaction such that it was consistently lower following three months incubation in the press treatments, with or without nutrient enrichment-respectively $21 \%$ and $16 \%$ lower at three and one month, but under freshwater pulses, shell $\left[\mathrm{Mg}^{2+}\right]$ content did not vary without nutrient enrichment but resulted in $22 \%$ lower content with increased 

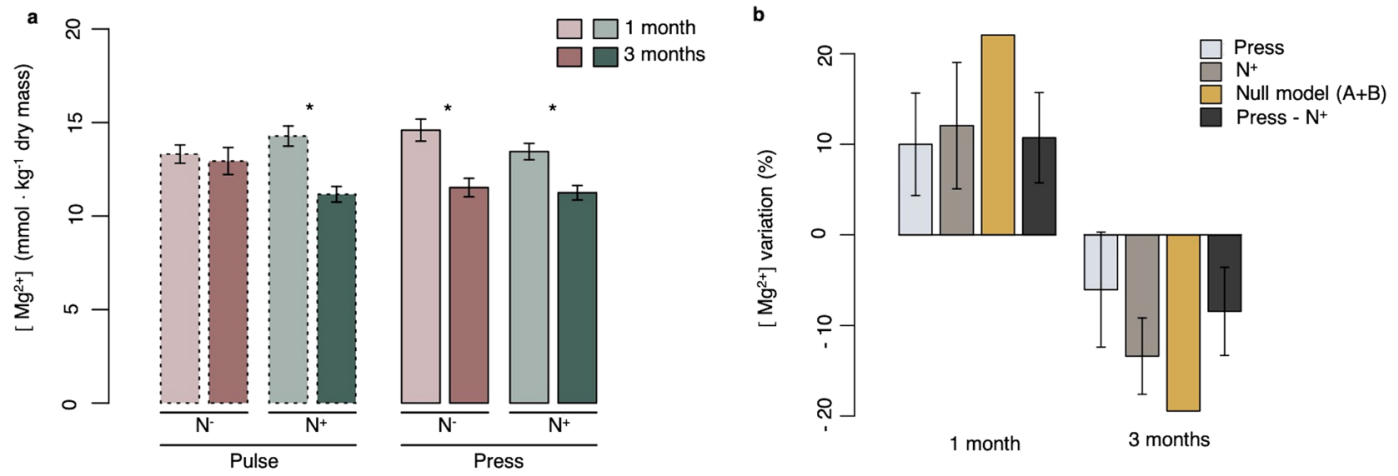

Figure 3. Effect of the interaction between salinity variation and nutrient enrichment through time on magnesium content in the shell of L. balthica. (a) Average magnesium content (mmol of $\mathrm{Mg}^{2+} \mathrm{kg}^{-1} \mathrm{dry}_{\text {mass}}$ ) for salinity treatments $(\mathrm{S})$ and nutrient concentrations $(\mathrm{N})$ at one and three months of exposure in L. balthica. Pair-wise contrasts showed a significant difference between the two exposure times for different combinations of salinity variation and nutrient conditions $(\mathrm{p}<0.05)$ as indicated by asterisks. Histograms represent mean values, and error bars correspond to standard errors. (b) Positive and negative antagonistic interaction between freshwater presses and nutrient enrichment through time based on a null additive model (yellow) $(S+N)$. Single effects of stressors, compared to the least stressful conditions, are shown in light blue and gray and combined effect is shown in dark gray. Error bars correspond to standard errors.

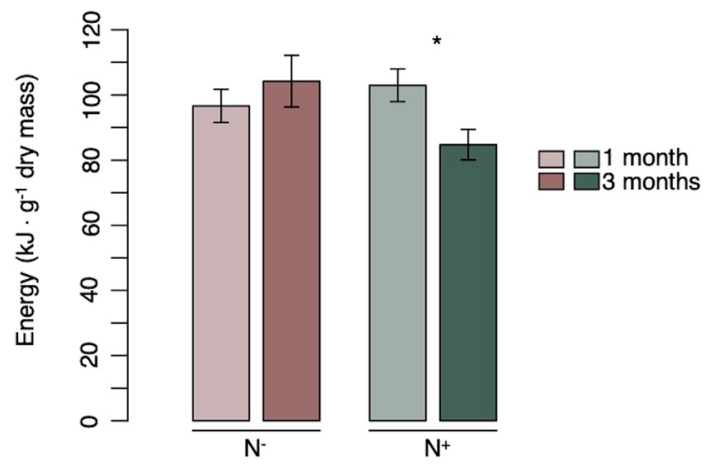

Figure 4. Effect of nutrient enrichment through time on energy content in the tissues of L. balthica. Average energy content ( $\mathrm{kJ} \mathrm{g}^{-1}$ dry mass) for nutrient conditions following one and three months exposure. Pair-wise contrasts showed a significant difference between one and three months of exposure under enriched nutrient conditions $(\mathrm{p}<0.05)$ as indicated by the asterisk. Histograms represent mean values, and error bars correspond to standard errors.

nutrients following three months incubation. The same pattern was observed for the $\mathrm{Mg}^{2+} / \mathrm{Ca}^{2+}$. Within the pulse treatment, the ratio was lower at three months with increased nutrients and, for the press treatment, it was always lower at three months regardless of nutrient concentrations. Based on a null additive model, the combined stressors consistently resulted in an antagonistic interaction at one and three months but in opposing directions (Fig. 3b). At one-month, individual stressors both had a positive effect, increasing shell $\left[\mathrm{Mg}^{2+}\right]$ when compared to the least stressful conditions. The response to the combined stressors was lower than expected and was classified as a positive antagonistic interaction. In contrast, after three months, individual stressors had reduced shell $\left[\mathrm{Mg}^{2+}\right]$. The combined effect of the press regime and nutrient enrichment was less negative than the additive expectation, resulting in a negative antagonistic effect. Exposure time alone impacted $\left[\mathrm{Sr}^{2+}\right]$ and $\mathrm{Sr}^{2+} / \mathrm{Ca}^{2+}$ with both being lower following three months (respectively, $19.626 \mathrm{mmol} \mathrm{kg}^{-1}$ dry shell and 0.0021 ) than one-month (respectively, $20.378 \mathrm{mmol} \mathrm{kg}^{-1}$ dry shell and 0.0022 ) exposure. Shell $\left[\mathrm{Ca}^{2+}\right]$ did not vary as a function of any of the combinations of stressors.

Energy content. In general, Mytilus sp. tissue energy content was significantly lower following one-month than three month's exposure (respectively, 29.634 and $38.550 \mathrm{~kJ} \mathrm{~g}^{-1}$ dry mass). Energy levels were not affected by any single or combined stressors (Table 4).

Overall, tissue energy content was relatively higher in L. balthica than Mytilus sp., with values reaching 99.792 and $94.604 \mathrm{~kJ} \mathrm{~g}^{-1}$ dry mass at one and three months, respectively. L. balthica tissue energy content was negatively affected by increased nutrients through time, as illustrated by a significant Exposure time $\times$ Nutrient interaction (Fig. 4, Table 4). In the absence of enriched nutrients, no significant difference was found between the two exposure times. In contrast, in the presence of added nutrients, there was a significant decrease of energy in 
tissues after three months of exposition. This highlights the dominance of the factor "Nutrient status" through time, this stressor having a positive effect on the shorter term than following a longer exposure. Mean energy content for all treatments are summarized for both species in Supplementary Table S2.

\section{Discussion}

Identifying and characterizing interactions among multiple stressors is of paramount importance to understand their effects on ecological systems and have been widely declared a major issue for conservation and management ${ }^{7}$. Our work highlights the importance of using appropriately designed experiments to understand the effects of multiple stressors, and does so for numerous responses, providing usable knowledge for management actions ${ }^{7}$. Below, we focus our discussion on the dominance of single stressors, the prevalence of antagonistic interactions between the evaluated stressors, and the relevance of considering results from experimental studies to guide management actions.

Dominances of single stressors and antagonistic effects. While stressors may interact to create non-linear responses, single stressors may also have dominant effects. Although dominances can be simpler to interpret than other processes, it may also create ecological surprise as stressors may have unexpected effects. For instance, this study shows a dominance of freshwater presses through time on microphytobenthos biomass and of nutrient enrichment on energy content in L. balthica. Increased chlorophyll $a$ concentration after three months under freshwater presses may be explained by species and assemblages of algae showing marked preferences or tolerances for low salinity conditions ${ }^{70}$. This suggests that salinity is an environmental factor that affects microphytobenthic species composition ${ }^{70}$. Originally, we expected a dominance of nutrient enrichment as field observations and laboratory experiments have shown this factor to stimulate the increase in microphytobenthic biomass ${ }^{71}$. However, nutrients did not increase chlorophyll $a$ concentration in the present study. The decrease in chlorophyll $a$ may also be interpreted at the community level, although our experiment was not specifically designed to investigate responses at this level of complexity. Increased chlorophyll $a$ concentration could be explained by decreased consumption by $L$. balthica in response to stress if the animal reduces depositfeeding activities ${ }^{72}$. Increased chlorophyll $a$ concentration under these conditions may also be explained by decreased consumption by Mytilus sp., given that mortality was increased when mussels were subjected to freshwater presses. Finally, as bivalves may discriminate among microalgal species ${ }^{73}$, variation in microphytobenthic species assemblages may have led to selective feeding and thus decreased filtering and deposit-feeding in both Mytilus sp. and L. balthica ${ }^{74}$.

Interestingly, a similar nutrient enrichment effect pattern over three months exposure time was observed for tissue energy content in L. balthica, which was lower in animals exposed to higher concentrations of nutrients at three months. This may be due to increased energetic costs that individuals incur to sustain homeostasis when subjected to toxic effects from different forms of nitrogen (e.g. ammonia) ${ }^{75}$, likely formed during our experiment, but these were not measured in this study. These effects may include proliferation of gill tissue, progressive acidosis, uncoupling of oxidative phosphorylation, and of osmo-ionic disruption ${ }^{75}$.

While synergies are quite easy to understand, antagonisms are less intuitive as it is hard to imagine how two stressors that, individually have negative effects on a given response, together cause a lesser negative effect ${ }^{7}$. An antagonism will more likely indicate that a positive effect of one stressor will overcompensate for the negative effect of another ${ }^{13}$. This type of interaction has been defined in different ways; we propose using the term antagonism as a synonym of "less-than" a predicted null model ${ }^{14,15}$. In our study, this is first illustrated by an antagonistic interaction between freshwater presses and nutrient enrichment for Mytilus sp. mortality. Freshwater presses increased mortality by $5 \%$ relative to the least stressful condition, while nutrients had no significant effect. Individual effects of nutrient inputs and salinity are well understood in this species and thus interpretation of the observed antagonism may be possible. Mytilus sp. is an osmoconformer, such that it maintains its extracellular fluid isotonic relative to the external environment ${ }^{76}$. The species is physiologically unable to maintain its hemolymph osmolarity over a range of salinities ${ }^{77}$ but it may tolerate reduced salinity by using intracellular volume control mechanisms to allow it to continue to feed, respire and maintain general cellular function ${ }^{77,78}$. Many studies have shown the effect of permanent low salinities (generally around $10 \mathrm{psu}$ ), frequency, and amplitude of salinity changes on mussel filtration, growth rate, early development and survival ${ }^{79-82}$. Previous studies have found variable effects of nutrient enrichment on bivalves. Positive effects of nutrient input on bivalves, specifically on Mytilus sp., include increased assimilation efficiency, biomass, and abundance due to increased food quantity ${ }^{83,84}$. In contrast, negative effects include increased mortality and reduced biomass ${ }^{85}$. This evidence supports the idea that nutrient enrichment has a detrimental or no effect on Mytilus sp. under lower osmotic stress (freshwater pulses) but appears to positively affect Mytilus sp. under higher osmotic stress (freshwater presses). This positive effect of nutrients under higher osmotic stress on Mytilus sp. survival could also have repercussions at the community-level. For instance, considering that food input was not limiting in our study, nutrients may have indirectly altered energy content in L. balthica by lowering mortality and increasing assimilation efficiency in Mytilus sp., decreasing food deposition to the sediments and availability for L. balthica. In fact, it has been shown that $L$. balthica switches between suspension- and deposit-feeding in response to the availability of suspended food particles and that deposit feeding increases with decreasing food concentrations in the water column ${ }^{86}$. Increased deposit feeding could explain why, in contrast to what we had first hypothesized, microphytobenthos was not more abundant under nutrient enriched conditions. This stresses the importance of considering different levels of organization when investigating the effect of stressor interactions, as the presence of species may alter predicted effects. 
An antagonistic interaction between salinity variation and nutrient enrichment was also detected for magnesium shell content of L. balthica. Magnesium content and $\left[\mathrm{Mg}^{2+}\right] /\left[\mathrm{Ca}^{2+}\right]$ in $L$. balthica were positively affected by both freshwater presses and nutrient enrichment, when compared to the least stressful conditions, following one-month exposure. Their combined effect was smaller than expected, resulting in a positive antagonism. In contrast, longer exposure yielded the opposite situation, with both stressors individually reducing shell magnesium content. Their combined effect was not as great as the null model, creating negative antagonism. This could be explained by several mechanisms. In the short term, individuals may either (1) not be affected by the stressors and be able to invest in mineralization, or (2) increase mineralization efforts in response to stress ${ }^{87,88}$. In contrast, following three-months exposure, these parameters are negatively impacted by the same stressors, with mean values being significantly lower. This may be explained by non-mutually exclusive mechanisms: (1) passive shell dissolution due to fluctuations in carbonate concentrations and seawater $\mathrm{pH},(2)$ active uptake of carbonate ions to buffer fluctuations in extra-cellular fluid osmo-ionic and acid-base status, and (3) changes in active mineralization. We may exclude passive dissolution as shell surface scouring and empty shell mass loss were not observed over the duration of the experiment. However, bivalves and other organisms possessing carbonate skeletons actively dissolve their shell to buffer (during short disturbances) their extra-cellular fluids ${ }^{89}$ to preserve their acid-base status. Acid-base status may be altered by a number of environmental disturbances, including salinity ${ }^{90}$ and nutrient ${ }^{75}$ changes. The modest reduction in $\left[\mathrm{Mg}^{2+}\right]$ observed, confirmed by reduced $\left[\mathrm{Mg}^{2+}\right] /\left[\mathrm{Ca}^{2+}\right]$, could support this pathway of action. Finally, we cannot completely exclude the possibility that the specimens may have also modified their active mineralization.

Using experimental studies to guide management actions. While identifying the outcome of every possible stressor combination in natural habitats is an impossible task, identifying generalities about stressors and responses through experimental work may create guidelines for conservation and management scientists ${ }^{7}$. For instance, the experimental work we carried out provides useful information for management by (1) informing on which stressors to act upon under different stressor interaction scenarios, and (2) providing details on which responses to investigate in natural ecosystems depending on the management objective.

Antagonistic interactions are often perceived as less of a concern than synergistic ones, since the impact of multiple stressors will be smaller than otherwise predicted, although acting on stressors without considering their potential interaction may waste effort and resources ${ }^{16}$. However, it is important to identify the type of interaction to avoid wrongly direct management efforts and waste resources ${ }^{16}$. Recent meta-analyses of experimental work on multiple stressors in marine, freshwater and terrestrial ecosystems have shown that antagonistic interactions are as common as synergistic interactions ${ }^{13,91}$. When synergistic effects must be managed, acting directly on local stressors will have the greatest ecosystem benefits ${ }^{16}$. In contrast, reducing local antagonistic stressors may have smaller benefits or even worsen stressor impacts ${ }^{16}$. Our results not only inform on stressor interactions, but also suggest that acting upon a stressor, like salinity variation, may result in the greatest benefit for bivalves, in terms of improved survival, and higher energy content in the tissues and magnesium content in the shell. In fact, this stressor had both dominant effects and interacted antagonistically with other stressors. In addition, acting on a local stressor, such as nutrient input, which had a dominant detrimental effect on energy content over a longer period, may be realistic for managers.

Finally, not all evaluated stressors affected all the biological responses of interest for both bivalves and microphytobenthos. This was to be expected as the effects of individual stressors vary with the level of biological complexity ${ }^{15,28}$, affecting some pathways, but not others. This implies that physiological/individual, population or community/ecosystem responses may be associated with more than one type of interaction ${ }^{7}$. For example, population-level responses tend to be most synergistically impacted by multiple stressors ${ }^{13}$. This indicates that focusing exclusively on individual-level responses could grossly underestimate population and ecosystem implications, with consequent implications for management and conservation actions ${ }^{15}$. For instance, our results show that stressors, alone and in combination, impacted individual species responses at both the population (mortality) and individual levels (shell mineralization, energy content). These results may help interpret specific changes in the biology of target species of interest for management and ultimately help understand changes in community responses ${ }^{15}$.

\section{Conclusion and recommendations}

In conclusion, experimental approaches, when based on realistic baseline conditions, are useful to help identify the stressors to act upon to maximize environmental management outcomes; efforts that are usually constrained by time and resources ${ }^{92}$. We also believe that focusing research on relevant local stressors (salinity variation, nutrient enrichment), within the context of global changes, on which managers can act directly, will be more useful for management and conservation actions.

We further believe that purposely designed experimental studies may inform managers on which component of the environment action is necessary. To that end, experiments must be designed to identify pathways of action and consider responses at the cellular, physiological, population and community level ${ }^{15}$. For example, results on mortality and cascading effects will be of great help for conservation practices, where the ultimate goal is often to maximize a species' demography and biodiversity. On the other hand, energy content results might be of greater interest for managers who deal with maintaining good levels of energy flow in trophic cascade in natural ecosystems, as well as ensuring a good status of commercial species, such as the blue mussel.

Experimental methods can be used to identify synergistic and antagonistic responses of multiple stressors, but will inevitably reach a complexity limit, as the feasibility of experiments decreases with the number of stressors considered. Generalities identified from experiments need to be validated using other methods, such as field observations and surveys, as well as in situ experiments, to take into account environmental complexity and 
feedbacks. We strongly believe that the integration of different approaches will ultimately contribute to addressing the challenges related to minimizing the cumulative impacts of future and ongoing multiple stressors on marine ecosystems.

Received: 9 September 2020; Accepted: 28 January 2021

Published online: 18 February 2021

\section{References}

1. Sanderson, E. W. et al. The human footprint and the last of the wild. Bioscience 52, 891-904 (2002).

2. Millenium Ecosystem Assessment. Ecosystems and Human Wellbeing: Wetlands and Water. World Resources Institute, Washington, DC. https://www.millenniumassessment.org/documents/document.358.aspx.pdf (2005).

3. Waters, C. N. et al. The Anthropocene is functionally and stratigraphically distinct from the Holocene. Science 351, aad2622. https ://doi.org/10.1126/science.aad2622 (2016).

4. Halpern, B. S. et al. Recent pace of change in human impact on the world's ocean. Sci. Rep. 9, 11609 (2019).

5. Vinebrooke, R. D. et al. Impacts of multiple stressors on biodiversity and ecosystem functioning: The role of species co-tolerance. Oikos 104, 451-457 (2004).

6. Hewitt, J. E., Ellis, J. I. \& Thrush, S. F. Multiple stressors, nonlinear effects and the implications of climate change impacts on marine coastal ecosystems. Glob. Chang. Biol. 22, 2665-2675 (2016).

7. Côté, I., Darling, E. \& Brown, C. Interactions among ecosystem stressors and their importance in conservation. Proc. R. Soc. Lond. B Biol. Sci. 283, 20152592. Doi: https://doi.org/10.1098/rspb.2015.2592 (2016).

8. Vörösmarty, C. J. et al. Global threats to human water security and river biodiversity. Nature 467, 555-561 (2010).

9. Séguin, A., Gravel, D. \& Archambault, P. Effect of disturbance regime on Alpha and Beta diversity of rock pools. Biodivers. J. 6, 1-17 (2014).

10. Halpern, B. S. et al. Spatial and temporal changes in cumulative human impacts on the world's ocean. Nat. Commun. 6, 1-7 (2015).

11. Folt, C. L., Chen, C. Y., Moore, M. V. \& Burnaford, J. Synergism and antagonism among multiple stressors. Limnol. Oceanogr. 44, 864-877 (1999).

12. Brook, B. W., Sodhi, N. S. \& Bradshaw, C. J. A. Synergies among extinction drivers under global change. Trends Ecol. Evol. 23, 453-460 (2008).

13. Crain, C. M., Kroeker, K. \& Halpern, B. S. Interactive and cumulative effects of multiple human stressors in marine systems. Ecol. Lett. 11, 1304-1315 (2008).

14. Piggott, J. J., Townsend, C. R. \& Matthaei, C. D. Reconceptualizing synergism and antagonism among multiple stressors. Ecol. Evol. 5, 1538-1547 (2015).

15. Galic, N., Sullivan, L. L., Grimm, V. \& Forbes, V. E. When things don't add up: quantifying impacts of multiple stressors from individual metabolism to ecosystem processing. Ecol. Lett. 21, 568-577 (2018).

16. Brown, C. J., Saunders, M. I., Possingham, H. P. \& Richardson, A. J. Managing for interactions between local and global stressors of ecosystems. PLoS ONE 8, e65765. https://doi.org/10.1371/journal.pone.0065765 (2013).

17. Brown, C. J., Saunders, M. I., Possingham, H. P. \& Richardson, A. J. Interactions between global and local stressors of ecosystems determine management effectiveness in cumulative impact mapping. Divers. Distrib. 20, 538-546 (2014).

18. Kaplan, I. C., Levin, P. S., Burden, M. \& Fulton, E. A. Fishing catch shares in the face of global change: A framework for integrating cumulative impacts and single species management. Can. J. Fish. Aquat. Sci. 67, 1968-1982 (2010).

19. Ghedini, G., Russell, B. D. \& Connell, S. D. Managing local coastal stressors to reduce the ecological effects of ocean acidification and warming. Water (Switzerland) 5, 1653-1661 (2013).

20. Hodgson, E. E., Halpern, B. S. \& Essington, T. E. Moving beyond silos in cumulative effects assessment. Front. Ecol. Evol. 7, 1-8 (2019).

21. Schindler, D. E. \& Hilborn, R. Prediction, precaution, and policy under global change. Science 347, 953-954 (2015).

22. Ling, S. D., Johnson, C. R., Frusher, S. D. \& Ridgway, K. R. Overfishing reduces resilience of kelp beds to climate-driven catastrophic phase shift. Proc. Natl. Acad. Sci. USA 106, 22341-22345 (2009).

23. Munday, P. L. et al. Ocean acidification impairs olfactory discrimination and homing ability of a marine fish. Proc. Natl. Acad. Sci. USA 106, 1848-1852 (2009).

24. Power, M. Assessing the effects of environmental stressors on fish populations. Aquat. Toxicol. 39, 151-169 (1997).

25. Hodgson, E. E., Essington, T. E. \& Halpern, B. S. Density dependence governs when population responses to multiple stressors are magnified or mitigated. Ecology 98, 2673-2683 (2017).

26. Griffith, G. P. \& Fulton, E. A. New approaches to simulating the complex interaction effects of multiple human impacts on the marine environment. ICES J. Mar. Sci. 71, 764-774 (2014).

27. Harvey, E., Séguin, A., Nozais, C., Archambault, P. \& Gravel, D. Identify effects dominate the impacts of multiple species extinctions on the functioning of complex food webs. Ecology 94, 169-179 (2013).

28. Schmolke, A., Brain, R., Thorbek, P., Perkins, D. \& Forbes, V. Population modeling for pesticide risk assessment of threatened species-A case study of a terrestrial plant Boltonia decurrens. Environ. Toxicol. Chem. 36, 480-491 (2017).

29. Calosi, P. et al. Adaptation and acclimatization to ocean acidification in marine ectotherms: An in situ transplant experiment with polychaetes at a shallow $\mathrm{CO}_{2}$ vent system. Philos. Trans. R. Soc. B, Biol. Sci. 368, (2013).

30. Alsterberg, C., Sundbäck, K. \& Hulth, S. Functioning of a shallow-water sediment system during experimental warming and nutrient enrichment. PLoS One 7, (2012).

31. Rosenberg, R. Eutrophication - The future marine coastal nuisance?. Mar. Pollut. Bull. 16, 227-231 (1985).

32. Levin, L. A. et al. Effects of natural and human-induced hypoxia on coastal benthos. Biogeosciences 6, 2063-2098 (2009).

33. McGlathery, K. J., Sundbäck, K. \& Anderson, I. C. Eutrophication in shallow coastal bays and lagoons: The role of plants in the coastal filter. Mar. Ecol. Prog. Ser. 348, 1-18 (2007).

34. Attrill, M. J. \& Power, M. Effects on invertebrate populations of drought-induced changes in estuarine water quality. Mar. Ecol. Prog. Ser. 203, 133-143 (2000).

35. McLusky, D. S., Hull, S. C. \& Elliott, M. Variations in the intertidal and subtidal macrofauna and sediments along a salinity gradient in the upper Forth estuary. Netherlands J. Aquat. Ecol. 27, 101-109 (1993).

36. Levinton, J., Doall, M., Ralston, D., Starke, A. \& Allam, B. Climate change, precipitation and impacts on an estuarine refuge from disease. PLoS ONE 6(4), e18849 (2011).

37. Greimel, F. et al. Hydropeaking impacts and mitigation in Riverine ecosystem management: Science for governing towards a sustainable future (ed. Schmutz, S. \& Sendzimir, J.) 91-110 (Aquatic Ecology Series 8, 2018).

38. Parmesan, C. \& Yohe, G. A globally coherent fingerprint of climate change. Nature 421, 37-42 (2003).

39. Jordà, G., Marbà, N. \& Duarte, C. M. Mediterranean seagrass vulnerable to regional climate warming. Nat. Clim. Chang. 2, 821-824 (2012). 
40. Lotzel, H. K. \& Worm, B. Complex interactions of climatic and ecological controls on macroalgal recruitment. Limnol. Oceanogr. 47, 1734-1741 (2002).

41. Paerl, H. W. \& Scott, J. T. Throwing fuel on the fire: Synergistic effects of excessive nitrogen inputs and global warming on harmful algal blooms. Environ. Sci. Technol. 44, 7756-7758 (2010).

42. Drejou, E. et al. Biodiversity and habitat assessment of coastal benthic communities in a sub-Arctic industrial harbour area. Water J. 12, 2424. https://doi.org/10.3390/w12092424 (2020).

43. Romero, F., Acuña, V., Font, C., Freixa, A. \& Sabater, S. Effects of multiple stressors on river biofilms depend on the time scale. Sci. Rep. 9, 15810. https://doi.org/10.1038/s41598-019-52320-42 (2019).

44. Borja, A., Franco, J. \& Pérez, V. A. A marine biotic index to establish the ecological quality of soft-bottom benthos within European estuarine and coastal environmentls. Mar. Pollut. Bull. 40, 1100-1114 (2000).

45. Bourget, E., Ardisson, P.-L., Lapointe, L. \& Daigle, G. Environmental factors as predictors of epibenthic assemblage biomass in the St Lawrence system. Estuar. Coast. Shelf. Sci. 57, 641-652 (2003).

46. McLusky, D.S. \& Allan, D.G. Aspects of the biology of Macoma balthica (L.) from estuarine Firth of Forth. J. Molluscan Stud. 42, 31-45 (1976).

47. Cottrell, R. S., Kenny, D. B., Hutchison, Z. L. \& Last, K. S. The influence of organic material and temperature on the burial tolerance of the blue mussel, Mytilus edulis: Considerations for the management of marine aggregate dredging. PLoS ONE 11, 1. https ://doi.org/10.1371/journal.pone.0147534 (2020).

48. Pearson, T. H. \& Rosenberg, R. Macrobenthic succession in relation to organic enrichment and pollution of the marine environment. Oceanogr. Mar. Biol. 16, 229-311 (1978).

49. Ratcliffe, P.J., Jones, N.V. \& Walters, N.J. The survival of Macoma balthica (L.) in mobile sediments. In Feeding and Survival Strategies of Estuarine Organisms (ed. Jones, N.V \& Wolff, W.J.) 91-108 (Plenum Press, 1981).

50. Riaux-Gobin, C. \& Klein, B. Microphytobenthic biomass measurement using HPLC and conventional pigment analysis. In Handbooks of Methods in Aquatic Microbial Ecology, (ed. Kemp, P.F., Sherr, B.F., Sherr, E.B. \& Cole, J.J.) 369-376 (Lewis Publishers, 1993).

51. Davies, B. E. Loss-on-ignition as an estimate of soil organic matter. Soil Sci. Soc. Am. J. 38, 150-151 (1974).

52. Wentworth, C. K. A scale of grade and class terms for clastic sediments. J. Geol. 30, 377-392 (1922).

53. Folk, R. L. \& Ward, W. C. Brazos River Bar: a study in the significance of grain size parameters. J. Sediment. Petrol. 27, 3-26 (1957).

54. Galbraith, P. et al. Physical oceanographic conditions in the Gulf of St. Lawrence during 2018. DFO Can. Sci. Advis. Sec. Res. Doc. 2019/046, iv + 69 p. (2019).

55. Baden, S., Boström, C., Tobiasson, S., Arponen, H. \& Moksnes, P. O. Relative importance of trophic interactions and nutrient enrichment in seagrass ecosystems: A broad-scale field experiment in the Baltic-Skagerrak area. Limnol. Oceanogr. 55, 1435-1448 (2010).

56. Moksnes, P.-O., Gullström, M., Tryman, K. \& Baden, S. Trophic cascades in a temperature seagrass community. Oikos 117, 763-777 (2008).

57. Bonsdorff, E. Establisment, growth and dynamics of a Macoma balthica (L.) population. Limnologica. 15, 403-405 (1984)

58. Castañeda, R. A., Cvetanovska, E., Hamelin, K. M., Simard, M. A. \& Ricciardi, A. Distribution, abundance and condition of an invasive bivalve (Corbicula fluminea) along an artificial thermal gradient in the St Lawrence River. Aquat. Invasions. 13, 379-392 (2018).

59. Baden, S. P. \& Eriksson, S. P. Role, routes and effects of manganese in crustaceans. Oceanogr. Mar. Biol. Ann. Rev. 44, 61-83 (2006).

60. Page, T. M., Worthington, S., Calosi, P. \& Stillman, J. H. Effects of elevated $\mathrm{pCO}_{2}$ on crab survival and exoskeleton composition depend on shell function and species distribution: A comparative analysis of carapace and claw mineralogy across four porcelain crab species from different habitats. ICES J. Mar. Sci. 74, 1021-1032 (2017).

61. Small, D., Calosi, P., White, D., Spicer, J. I. \& Widdicombe, S. Impact of medium-term exposure to $\mathrm{CO}_{2}$ enriched seawater on the physiological functions of the velvet swimming crab Necora puber. Aquat. Biol. 10, 11-21 (2010).

62. Marchant, H. K., Calosi, P. \& Spicer, J. I. Short-term exposure to hypercapnia does not compromise feeding, acid-base balance or respiration of Patella vulgata but surprisingly is accompanied by radula damage. J. Mar. Biol. Assoc. UK 90, 1379-1384 (2010).

63. Horne, F.R. \& Tarsitano, S. The mineralization and biomechanics of the exoskeleton. In The Biology and Fisheries of the Slipper Lobster (ed. Lavalli, K.L \& Spanier, E.) 183-189 (CRC Press, 2007).

64. Tao, J., Zhou, D., Zhang, Z., Xu, X. \& Tang, R. Magnesium-aspartate-based crystallization switch inspired from shell molt of crustacean. Proc. Natl. Acad. Sci. USA 106, 22096-22101 (2009).

65. Menu-Courey, K. et al. Energy metabolism and survival of the juvenile recruits of the American lobster (Homarus americanus) exposed to a gradient of elevated seawater $\mathrm{pCO}_{2}$. Mar. Environ. Res. 143, 111-123 (2019).

66. Siddon, E. C., Heintz, R. A. \& Mueter, F. J. Conceptual model of energy allocation in walleye pollock (Theragra chalcogramma) from age-0 to age-1 in the southeastern Bering Sea. Deep Sea Res. Part II Top. Stud. Oceanogr. 94, 140-149 (2013).

67. Anderson, M. J. Permanova: A fortran computer program for permutational multivariate analysis of variance (University of Auckland, Auckland, Department of Statistics, 2005).

68. Clarke, K.R \& Gorley, R.N. PRIMER v6: User Manual/Tutorial (Plymouth Routines in Multivariate Ecological Research). PRIMERE, Plymouth (2006).

69. Sih, A., Englund, G. \& Wooster, D. Emergent impacts of multiple predators on prey. Trends Ecol. Evol. 13, 350-355 (1998).

70. Thornton, D. C. O., Dong, L. F., Underwood, G. J. C. \& Nedwell, D. B. Factors affecting microphytobenthic biomass, species composition and production in the Colne Estuary (UK). Aquat. Microb. Ecol. 27, 285-300 (2002).

71. Pinckney, J., Paerl, H. W. \& Fitzpatrick, M. Impacts of seasonality and nutrients on microbial mat community structure and function. Mar. Ecol. Prog. Ser. 123, 207-216 (1995).

72. Lin, J. \& Hines, A. H. Effects of suspended food availability on the feeding mode and burial depth of the Baltic clam Macoma balthica. Oikos 69, 28-36 (1994).

73. Bougrier, S., Hawkins, A. J. S. \& Héral, M. Preingestive selection of different microalgal mixtures in Crassostrea gigas and Mytilus edulis, analyzed by flow cytometry. Aquaculture 150, 123-134 (1997).

74. Cognie, B., Barillé, L. \& Rincé, Y. Selective feeding of the oyster Crassostrea gigas fed on a natural microphytobenthos assemblage. Estuaries Coast. 24, 126-131 (2001).

75. Camargo, J. A. \& Alonso, Á. Ecological and toxicological effects of inorganic nitrogen pollution in aquatic ecosystems: A global assessment. Environ. Int. 32, 831-849 (2006).

76. Davenport, J. \& Redpath, K.J. Copper and the mussel Mytilus edulis (L.) in Toxins, drugs and pollutants in marine animals (ed. Bolis, L., Zadunaisky, J. \& Gilles, R.) 176-189 (Springler-Verlag, 1984).

77. Gosling, E. Bivalve Molluscs: Biology, Ecology and Culture (ed. Blackwell Publishing) 95-96 (Wiley-Blackwell, 2003).

78. Hauton, C. Physiological responses: Effects of salinity as a stressor to aquatic in- vertebrates. In Stressors in the Marine Environment: Physiological and Ecological Responses; Societal Implications (ed. Solan, M \& Whiteley, N.M.) 3-24 (Oxford University Press, 2016)

79. Almada-Villela, P. C. The effects of reduced salinity on the shell growth of small Mytilus edulis. J. Mar. Biol. Assoc. U.K. 64, 171-182 (1984).

80. Kautsky, N., Johannesson, K. \& Tedengren, M. Genotypic and phenotypic differences between Baltic and North Sea populations of Mytilus edulis evaluated through reciprocal transplantations. I. Growth and morphology. Mar. Ecol. Prog. Ser. 59, $203-210$ (1990). 
81. Westerbom, M., Kilpi, M. \& Mustonen, O. Blue mussels, Mytilus edulis, at the edge of the range: Population structure, growth and biomass along a salinity gradient in the north-eastern Baltic Sea. Mar. Biol. 140, 991-999 (2002).

82. Qiu, J., Tremblay, R. \& Bourget, E. Ontogenetic changes in hyposaline tolerance in the mussels Mytilus edulis and M. trossulus: implications for distribution. Mar. Ecol. Prog. Ser. 228, 143-152 (2002).

83. Cederwal, H. \& Elmgren, R. Biomass increase of benthic macro- fauna demonstrates eutrophication of the Baltic Sea. Ophelia Suppl. 1, 287-304 (1980).

84. Josefson, A. B. \& Rasmussen, B. Nutrient retention by benthic macrofaunal biomass of Danish estuaries: Importance of nutrient load and residence time. Estuar. Coast. Shelf Sci. 50, 205-216 (2000).

85. Carmichael, R. H., Shriver, A. C. \& Valiela, I. Bivalve response to estuarine eutrophication: The balance between enhanced food supply and habitat alterations. J. Shellfish Res. 31, 1-11 (2012).

86. Lin, J. \& Hines, A. Effects of suspended food availability on the feeding mode and burial depth of the Baltic clam. Macoma balthica. Oiko 69, 28-36 (1994).

87. Findlay, H. S. et al. Comparing the impact of high $\mathrm{CO}_{2}$ on calcium carbonate structures in different marine organisms. Mar. Biol. Res. 7, 565-575 (2011).

88. Ries, J.B., Cohen. A.L. \& McCorkle, D.C. Marine calcifiers exhibit mixed responses to $\mathrm{CO}_{2}$-induced ocean acidification. Geology 37, 1131-1134 (2009).

89. Michaelidis, B., Ouzounis, C., Paleras, A. \& Pörtner, H. O. Effects of long-term moderate hypercapnia on acid-base balance and growth rate in marine mussels Mytilus galloprovincialis. Mar. Ecol. Prog. Ser. 293, 109-118 (2005).

90. Whiteley, N. M., Scott, J. L., Breeze, S. J. \& McCann, L. Effects of water salinity on acid-base balance in decapod crustaceans. J. Exp. Biol. 204, 1003-1011 (2001).

91. Darling, E. S. \& Côté, I. M. Quantifying the evidence for ecological synergies. Ecol. Lett. 11, 1278-1286 (2008).

92. Withey, J. C. et al. Maximizing return on conservation investment in the conterminous USA. Ecol. Lett. 15, 1249-1256 (2012).

\section{Acknowledgements}

This project was funded by the Natural Sciences and Engineering Research Council of Canada's (NSERC) Strategic Network, Canadian Healthy Oceans Network (CHONe) (Grant ID: 468437), and its partners: Fisheries and Oceans Canada and the Northern Institute for Research in Environment and Occupational Health and Safety (INREST), representing the Port de Sept-Îles and Ville de Sept-Îles. This work was also supported by Québec Océan and is a contribution to the research programs of Québec-Océan and Takuvik. We thank C.-A. Parent, J. Tedeschi, L. Hiserman, C. Riley, R. Léger-Daigle, and R. Estrada for technical assistance during the experimental phase and M.-V. Loiseau, B. Chambon, L. Rieger, F. Baumans, A. Atikesse, and F. M. Couture-Charron during the laboratory work for determining tissue energy and shell mineral content. We thank D. Beauchesne and E. Dreujou for help with coding and statistical analyses. We also thank Prof. P. Calosi for helping identifying physiological traits to be measured and interpreting physiological results. Finally, we thank the Fédération Québécoise des chasseurs et pêcheurs (FédéCP) for supporting this work through its graduate scholarship program.

\section{Author contributions}

Conceived and designed the experiment: C.C.B., D.D., C.W.M., P.A. Performed the experiments: C.C.B, D.D. Performed the laboratory analysis: C.C.B. Analyzed the data: C.C.B. Wrote the paper: C.C.B. All authors reviewed the final paper. Funding was obtained by P.A. and C.W.M.

\section{Competing interests}

The authors declare no competing interests.

\section{Additional information}

Supplementary Information The online version contains supplementary material available at https://doi. org/10.1038/s41598-021-83533-1.

Correspondence and requests for materials should be addressed to C.C.-B.

Reprints and permissions information is available at www.nature.com/reprints.

Publisher's note Springer Nature remains neutral with regard to jurisdictional claims in published maps and institutional affiliations.

(c) (i) Open Access This article is licensed under a Creative Commons Attribution 4.0 International License, which permits use, sharing, adaptation, distribution and reproduction in any medium or format, as long as you give appropriate credit to the original author(s) and the source, provide a link to the Creative Commons licence, and indicate if changes were made. The images or other third party material in this article are included in the article's Creative Commons licence, unless indicated otherwise in a credit line to the material. If material is not included in the article's Creative Commons licence and your intended use is not permitted by statutory regulation or exceeds the permitted use, you will need to obtain permission directly from the copyright holder. To view a copy of this licence, visit http://creativecommons.org/licenses/by/4.0/.

(c) The Author(s) 2021 